\title{
Cytomegalovirus in Plasma of Acute Coronary Syndrome Patients
}

\author{
E. A. Nikitskaya1, J.-C. Grivel2+, E. V. Maryukhnich', A. M. Lebedeva', O. I. Ivanova', \\ P. P. Savvinova ${ }^{1}$, A. V. Shpektor ${ }^{1}$, L. B. Margolis ${ }^{2}$, E. Yu. Vasilieva ${ }^{1 *}$ \\ 'Laboratory of Atherothrombosis, Cardiology Department, Evdokimov Moscow State University of \\ Medicine and Dentistry, Delegatskaya str. 20/1, 127473, Moscow, Russia; \\ ${ }^{2}$ Section on Intercellular Interactions, Eunice Kennedy Shriver National Institute of Child Health and \\ Human Development, National Institutes of Health, Bethesda, MD, USA \\ +Current affiliation: Sidra Medical and Research Center, P.O. Box 26999, Doha, Qatar \\ *E-mail: vasilievahelena@gmail.com \\ Received 02.09.2015 \\ Copyright @ 2016 Park-media, Ltd. This is an open access article distributed under the Creative Commons Attribution License, which permits \\ unrestricted use, distribution, and reproduction in any medium, provided the original work is properly cited.
}

ABSTRACT The relationship between acute coronary syndrome (ACS) and local and systemic inflammation, including accumulation of macrophages in atherosclerotic plaques and upregulation of blood cytokines (e.g., C-reactive protein (CRP)), has been known for more than 100 years. The atherosclerosis-associated inflammatory response has been traditionally considered as an immune system reaction to low-density lipoproteins. At the same time, some data have indicated a potential involvement of cytomegalovirus (CMV) in the activation and progression of atherosclerosis-associated inflammation, leading to ACS. However, these data have been tangential and mainly concerned the relationship between a coronary artery disease (CAD) prognosis and the anti-CMV antibody titer. We assumed that ACS might be associated with CMV reactivation and virus release into the bloodstream. The study's aim was to test this assumption through a comparison of the plasma CMV DNA level in patients with various CAD forms and in healthy subjects. To our knowledge, no similar research has been undertaken yet. A total of 150 subjects (97 CAD patients and 53 healthy subjects) were examined. Real-time polymerase chain reaction (RT-PCR) was used to determine the number of plasma CMV DNA copies. We demonstrated that the number of plasma CMV genome copies in ACS patients was significantly higher than that in healthy subjects $(p=0.01)$. The CMV genome copy number was correlated with the plasma CRP level ( $p$ $=0.002$ ). These findings indicate a potential relationship between CMV activation and atherosclerosis exacerbation that, in turn, leads to the development of unstable angina and acute myocardial infarction. Monitoring of the CMV plasma level in CAD patients may be helpful in the development of new therapeutic approaches to coronary atherosclerosis treatment.

KEYWORDS coronary artery disease, acute coronary syndrome, human herpes viruses, cytomegalovirus, polymerase chain reaction.

ABBREVIATIONS HHV - human herpes virus; hs-CRP - high-sensitivity C-reactive protein; CAD - coronary artery disease; AMI - acute myocardial infarction; SCAD - stable coronary artery disease; ACS - acute coronary syndrome; RT-PCR - real time polymerase chain reaction; CMV - cytomegalovirus.

\section{INTRODUCTION}

Atherosclerotic coronary artery lesions often lead to the development of a coronary artery disease (CAD) that manifests itself as angina or painless myocardial ischemia. This disease can last for years as stable coronary artery disease (SCAD) forms, with occasional exacerbations presenting themselves clinically as unstable angina or acute myocardial infarction (AMI). These clinical manifestations are grouped under the name of acute coronary syndrome (ACS). The morphological substrate of this exacerbation is supposed to be acute inflammation followed by atherosclerotic plaque rupture and thrombosis formation [1-3]. Despite the fact that the role of inflammation in the development and progression of atherosclerosis has been under discussion for the second century running since the time of Virchow [4], the causes of this inflammation are not completely clear. The very fact of an inflammation is confirmed by the presence of macrophages and lymphocytes in the plaques, an elevated level of inflammatory cytokines in atherosclerosis patients, etc. [5-10]. According to the most accepted theory, the primary trigger of an inflammatory reaction in the vascular wall is the subendothelial accumulation of oxidized low-density lipoproteins [11-13]. At the same time, there are data indicating that atherosclerotic plaques 
contain various bacteria and viruses [14-19] that can also induce an inflammatory response. Herpesviruses, in particular the cytomegalovirus (CMV), are of huge interest. Many epidemiological studies have revealed a relationship among the incidence of coronary atherosclerosis, the incidence of acute myocardial infarction, and the blood level of anti-CMV antibodies [20,21]. However, this is insufficient to assess the viral infection activity during atherosclerosis exacerbation. An exception is a study by S. Gredmark et al. [22], demonstrating that CMV RNA in the monocytes of ACS patients occurs more often than in those of healthy donors and patients with chronic forms of CAD, which may indicate activation of the virus during ACS. At the same time, no direct analysis of the plasma CMV level in patients with atherosclerotic coronary artery disease has been previously performed. The presence of the virus in plasma may indicate its activation [23-25]. In this work, we present a comparative study of CMV in plasma of patients with various forms of CAD and healthy volunteers.

\section{MATERIAL AND METHODS}

\section{Characterization of groups of patients}

and healthy volunteers

The study involved 150 participants, including $97 \mathrm{CAD}$ patients and 53 healthy volunteers. Seventy-one patients were admitted to the Cardiac Critical Care Department of the Davydovskiy Municipal Clinical Hospital with a diagnosis of acute coronary syndrome. Of these, 47 patients were diagnosed with AMI with or without ST-segment elevation in accordance with the universal definition of the European Society of Cardiology [26]; unstable angina was diagnosed in 24 cases. Twenty-six patients were admitted electively. CAD was diagnosed based on the clinical picture and positive stress test results, which was later confirmed by coronary angiography [27]. In all patients, the clinical prognosis was evaluated; there were no cases of death, hemodynamically significant bleeding, stroke, or stent thrombosis. At admission, two ACS patients were diagnosed with cardiogenic shock; two patients had acute heart failure; 12 patients had acute left ventricular aneurysm; seven patients with a severe coronary artery disease had repeated angina attacks.

An examination of healthy volunteers included a survey, blood chemistry, ultrasound of the heart and carotid arteries, and a stress test. According to the examination data, no subjects with signs of atherosclerosis were identified in the control group.

Patient groups did not differ in age or gender, but they differed in the presence of risk factors, such as obesity, arterial hypertension, and diabetes (Table 1).

All participants provided a written informed consent to participate in this study. The study was approved by the local ethics committee of the Evdokimov Moscow State University of Medicine and Dentistry.

\section{Isolation of viral DNA from plasma}

In all patients, a 5 -mL blood sample was collected into a test tube with sodium citrate within $24 \mathrm{~h}$ after admission. Blood samples were centrifuged at 2,500 rpm for $10 \mathrm{~min}$, after which the plasma was collected, frozen in sterile test tubes, and stored at $-80^{\circ} \mathrm{C}$ until further use.

The samples were thawed, and DNA was isolated from the plasma using QIAamp DNA Blood mini kit columns (Qiagen, Germany) according to a standard protocol. Elution was performed using $60 \mu \mathrm{L}$ of a special buffer from the same kit. Before conducting the real-time polymerase chain reaction (RT-PCR), DNA samples were stored at $-20^{\circ} \mathrm{C}$.

Table 1. Clinical characteristics of CAD patients and healthy volunteers

\begin{tabular}{|c|c|c|c|c|}
\hline Indicator & ACS patients & SCAD patients & Healthy volunteers & $\mathrm{p}$ \\
\hline Number of patients & 71 & 26 & 53 & 0.116 \\
\hline Mean age & $64.4 \pm 9.7$ & $66.3 \pm 10.6$ & $61.3 \pm 12.3$ & 0.298 \\
\hline Males & $63.4 \%$ & $65.4 \%$ & $50.9 \%$ & 0.205 \\
\hline Smoking & $28.2 \%$ & $11.5 \%$ & $20.8 \%$ & 0.135 \\
\hline Hyperlipidemia & $35.2 \%$ & $15.4 \%$ & $34.0 \%$ & $0.001^{*}$ \\
\hline Obesity & $45.1 \%$ & $23.1 \%$ & $15.1 \%$ & $0.000^{*}$ \\
\hline Hypertension & $90.1 \%$ & $92.3 \%$ & $47.2 \%$ & $0.0002^{*}$ \\
\hline
\end{tabular}

The clinical characteristics of all three groups of patients are presented.

"Differences are statistically significant at $p<0.05$. 
Table 2. CMV primers and probes

\begin{tabular}{|c|c|c|c|}
\hline Probe/Primer & Nucleotide sequence & 5'-modification & 3'-modification \\
\hline Probe & tacctggagtccttctgcgagga & CAL Fluor Red $610^{*}$ & BHQ-2* \\
\hline Forward primer & aaccaagatgcaggtgatagg & & \\
\hline Reverse primer & agcgtgacgtgcataaga & & \\
\hline
\end{tabular}

"CAL Fluor Red 610 is a fluorescent label on the probe. "BHQ-2 is a fluorescence quencher.

\section{Quantitative RT-PCR}

CMV was detected by RT-PCR (CFX 96 C1000 Touch Thermal Cycler, Bio-Rad, USA) using highly sensitive primers and a 5'-3'-hydrolyzable probe to the CMV tegument protein pp65 gene (Table 2). Amplification was evaluated from the standard curve using standard dilution series (Bioresearch Technologies, USA) and ToughMix PCR mixtures (Quanta, USA, Cat \# 95147-250).

RT-PCR was performed according to the standard three-step protocol: step 1 - denaturation at $95^{\circ} \mathrm{C}$ for $5 \mathrm{~min}$, step $2-95^{\circ} \mathrm{C}$ for $30 \mathrm{~s}$, and step $3-60^{\circ} \mathrm{C}$ for $60 \mathrm{~s}$.

Next, the fluorescence signal was detected.

The second and third steps were again repeated for 45 cycles. Fluorescence detectable up to the $37 \mathrm{th}$ cycle was considered specific. The results were presented as the CMV DNA copy number in $1 \mu \mathrm{L}$ of the patient blood plasma.

\section{Measurement of the high-sensitivity}

C-reactive protein (hs-CRP)

At admission, all patients underwent an analysis of hs$\mathrm{CRP}$, whose level is correlated with the risk of cardiovascular events [28]. The protein plasma level was determined on an automatic analyzer (Siemens Dimention Xpand Plus, Germany) using a C-Reactive Protein Flex Reagent kit (Siemens \# DF37, Germany).

\section{Statistical data processing}

The statistical analysis was performed using the Statistica 9.0 software. All obtained data had no signs of a normal distribution based on the Shapiro-Wilk test and, therefore, were represented as median and interquartile ranges. Because of the non-parametric distribution, the Mann-Whitney test was used for comparison between two groups. Non-parametric statistics with the Kruskal-Wallis test and multiple comparison rank test were used to compare more than two groups. The Spearman correlation coefficient was also used. Differences between groups were considered statistically significant at the level of $p<0.05$.

\section{RESULTS AND DISCUSSION}

Small CMV DNA concentrations (over 100 copies in 1 $\mu \mathrm{L}$ of blood plasma) were quite frequently found both in patients and in healthy volunteers. The rate of virus detection in the three groups differed statistically significantly and was highest in ACS patients (Table 3).

Comparison of the number of CIMV DNA copies in three groups revealed significant differences between ACS patients and healthy volunteers (213.15 [101.21-436.67] versus 82.10 [18.58-188.67], respectively, $p=0.012$ ). However, no statistically significant differences between the group of chronic CAD patients and the group of healthy volunteers were found. The results are shown in Fig. 1. In addition, a statistically significant ( $p=0.002$ ) positive correlation between the number of CMV copies and the hs-CRP level was found in this cohort (Fig. 2).

Therefore, we had demonstrated that the occurrence and number of CMV copies in the blood plasma of patients with acute CAD forms were significantly higher than those in healthy controls. No differences between the chronic CAD group and the control group were found.

These findings demonstrate that a small amount of the virus is quite often present in the plasma of healthy individuals (Table 3). This is consistent with epidemiological study data on a CMV-seropositive adult population in various countries [24, 29-30]. Our data indicate that the number of CMV DNA copies can substantially increase in pathology: in the case of ACS, the number was more than 2 times higher than that in healthy volunteers. Our findings are generally consistent with

Table 3. The CMV occurrence rate in different groups

\begin{tabular}{|c|c|c|c|c|}
\hline & $\begin{array}{c}\text { Healthy } \\
\text { volunteers }\end{array}$ & $\begin{array}{c}\text { ACS } \\
\text { patients }\end{array}$ & $\begin{array}{c}\text { SCAD } \\
\text { patients }\end{array}$ & p \\
\hline $\begin{array}{c}\text { Number of } \\
\text { virus-positive } \\
\text { patients }\end{array}$ & $\begin{array}{c}46.15 \% \\
(18 / 39)\end{array}$ & $\begin{array}{c}77.08 \% \\
(37 / 48)\end{array}$ & $\begin{array}{c}55.56 \% \\
(10 / 18)\end{array}$ & 0.013 \\
\hline
\end{tabular}


epidemiological data on the correlation between the presence of CMV and atherosclerosis progression, with allowance for the anti-CMV antibody titer [31]. For example, one of the epidemiological studies had revealed a correlation between cardiovascular disease mortality and the anti-CMV antibody titer level [17]. An ARIC study also showed that cardiovascular disease mortality was proportional to an increase in the carotid artery intima-media thickness [32]. However, results of seroepidemiological studies are contradictory. For example, a prospective, controlled study by P.M. Ridker et al. revealed no relationship between the presence of anti-CMV antibodies and the risk of atherothrombotic events. In this case, the antibody titer height was not evaluated separately [33].

Previously, the herpesvirus DNA was identified in plaques and blood monocytes by PCR [34]. Melnick et al. [35] demonstrated for the first time that CMV DNA was present in the artery walls of atherosclerosis patients. The viral DNA concentration was higher in the arterial wall of patients who underwent reconstructive vascular surgery (coronary artery bypass grafting) compared to patients with early atherosclerosis [36]. Later, CMV was found in the atherosclerotic plaques [37]. We also studied samples obtained from patients who had died of acute myocardial infarction or its complications, but we did not find significant differences in the number of CMV DNA copies in the atherosclerotic plaques and coronary arteries without macroscopic signs of atherosclerosis [38].

The inconsistency of these data may be associated with the fact that both CMV seropositivity and the presence of CMV DNA in tissues and blood cells are not sufficient to conclude on virus replication. In the present work, the number of CMV DNA copies was determined in the plasma of patients with various CAD forms. The presence of the virus in plasma indicates productive infection [23, 24, 29-30]. Another indicator of productive infection may be the presence of CMV RNA, which was detected in peripheral blood mononuclear cells [22]. The amount of CMV RNA in blood monocytes of ACS patients was significantly higher than that in stable angina patients and healthy subjects $(p<0.001)$. In this case, the occurrence of CMV RNA in monocytes was relatively small and amounted to $2 \%$ in healthy volunteers, $10 \%$ in SCAD patients, and 15\% in ACS patients [22]. In general, these data are consistent with the results of our work. However, the occurrence rate of the virus in our groups was higher, possibly due to the fact that blood monocytes are not the only body cells secreting CMV into the plasma.

The morphological basis of ACS is an atherosclerotic plaque rupture, probably due to inflammation in the plaque. A number of studies using histochemical tech-

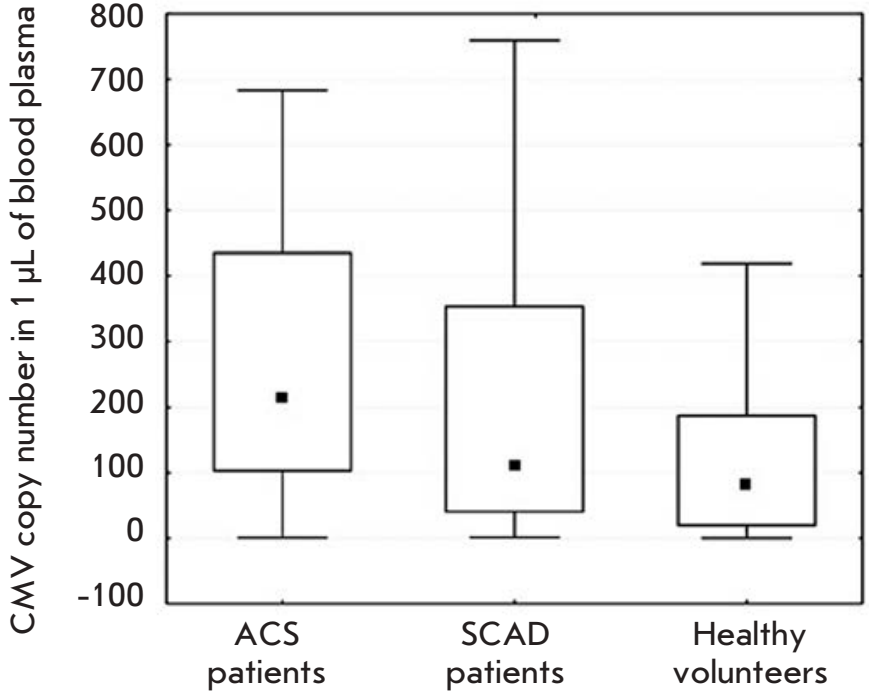

Fig. 1. Comparison of the CMV DNA copy number in the blood plasma of patients in the study groups. The median and 25th-75th percentiles of the CMV DNA copy number in the three groups are presented. Statistically significant differences were found between the ACS group and the healthy volunteer group $(p=0.012)$.

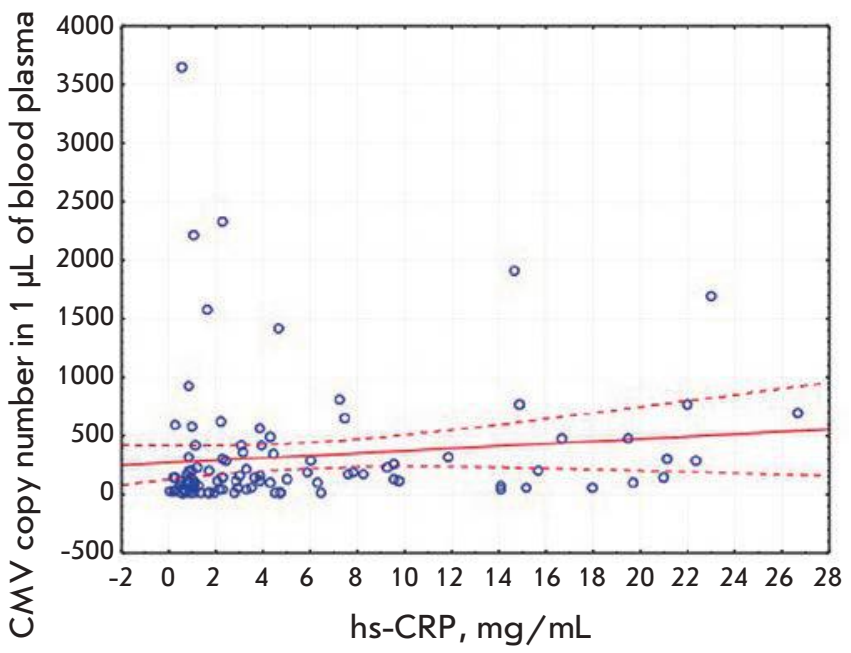

Fig. 2. A correlation between the CMV genome copy number and the hs-CRP level is shown. Results of an individual analysis of the CMV copy number and hs-CRP level are presented. A correlation between the indicators with $95 \%$ confidence intervals is demonstrated. Two samples exceeding the mean cohort values by almost 10 times were excluded from the analysis. The correlation coefficient R was $0.25(p=0.011)$ before excluding the samples and $0.30(p=0.002)$ after exclusion. 
niques have demonstrated that the plaques contain activated lymphocytes and macrophages [11, 12, 39-42]. Previously, we used an original technique for isolation of cells from the plaque, preserving cell surface antigens, and their evaluation by flow cytometry [43]. This enabled us to quantitatively evaluate the number of activated lymphocytes $\left(\mathrm{CD} 8^{+} \mathrm{CD} 25^{+}\right.$and $\left.\mathrm{CD} 8^{+} \mathrm{HLA}-\mathrm{DR}^{+}\right)$ in the plaques, which happened to be significantly higher than that in the blood. In other studies, along with those by our group, a number of bacteria and viruses, including CMV, were found in blood vessels using RT-PCR [38]. This may be the cause of chronic activation of the immune system in vessels, stimulating the development of atherosclerosis [44]. The role of either oxidized lipoproteins or microorganisms in this activation remains unclear. It may not be excluded that detection of viruses in blood vessels is not related to atherosclerosis itself. They may be present in the vascular wall without playing any pathogenetic role in the development of this pathology. The data obtained in this study disprove this assumption: an elevated CMV DNA level in the plasma of ACS patients indicated enhanced virus replication upon atherosclerosis exacerbation. It is not clear whether the CMV activation plays the major role in the atherosclerosis progression, or other microorganisms may also be involved in this process. Also, the relationship between two factors, CMV reproduction and hyperlipidemia, has not been determined yet. A combination of both mechanisms is possible: CMV reproduction in the plaque may be accompanied by more active lipoprotein accumulation by macrophages. Lipoproteins subjected to oxidization, in turn, may enhance inflammatory reactions in the vascular wall. To answer these questions, further research is needed. The promising area seems to be further analysis of the CMV plasma level in patients with various forms of coronary atherosclerosis and comparison of the virus level with changes in the disease clinical picture.

\section{CONCLUSION}

Thus, we have demonstrated the fact of CMV activation in ACS patients. The number of CMV DNA copies in the plasma is correlated with the level of hs-CRP, a systemic inflammation marker. CMV activation is probably one of the mechanisms triggering the inflammatory process in the atherosclerotic plaque, which leads to disruption of the plaque integrity and subsequent thrombus formation. Further investigation of the mechanisms of CMV effects on atherosclerosis progression may be helpful in developing new approaches to the treatment of CAD.

This work was supported by a grant of the Ministry of Education and Science of the Russian Federation (o. 14.V25.31.0016).

Collaborative research by J.-C. Grivel and

L.B. Margolis was supported by an internal program of the U.S. National Institutes of Health.
REFERENCES

1. Hamm C.V., Murray C.J., Lopez A.D. // Lancet. 1997. V. 349. P. $1498-1504$.

2. Hamm C.W., Bassand J.P., Agewall S., Bax J. Boersma E., Bueno H., Caso P., Dudek D., Gielen S., Huber K., et al. // Eur. Heart J. 2011. V. 32. P. 2999-3054.

3. Steg P.G., James S.K., Atar D., Badano L.P., Blömstrom-Lundqvist C., Borger M.A., Di Mario C., Dickstein K., Ducrocq G., Fernandez-Aviles F., et al. // Eur. Heart J. 2012. V. 33. P. 2569-2619.

4. Virchow R. // Cellular pathology. Translation from German. Mocow Medicine, 1859.

5. Galkina E., Ley K. // Annu. Rev. Immunol. 2009. V. 27. P. 165-197.

6. Harja E., Bu D.X., Hudson B.I., Chang J.S., Shen X., Hallam K., Kalea A.Z., Lu Y., Rosario R.H., Oruganti S., et al. // J. Clin. Invest. 2008. V. 118. № 1. P. 183-194.

7. Muller W.A. // Circ. Res. 2009. V. 105. № 3. P. 223-230.

8. Galkina E., Kadl A., Sanders J., Varughese D., Sarembock I.J., Ley K. // J. Exp. Med. 2006. V. 203. № 5. P. 1273-1282.

9. Ait-Oufella H., Taleb S., Mallat Z., Tedgui A. // Arterioscler. Thromb. Vasc. Biol. 2011. V. 31. № 5. P. 969-979.

10. van Berkel T.J., Out R., Hoekstra M., Kuiper J., Biessen E., van Eck M. // Curr. Opin. Lipidol. 2005. V. 16. № 5. P. $525-535$.
11. Geng Y.J., Libby P. // Arterioscler. Thromb. Vasc. Biol. 2002. V. 22. № 9. P. 1370-1380.

12. Kruth H.S. // Curr. Opin. Lipidol. 2002. V. 13. № 5. P. 483-491. 13. Zhu J., Nieto F.J., Horne B.D., Anderson J.L., Muhlestein J.B., Epstein S.E. // Circulation. 2001. V. 103. № 1. P. 45-51. 14. Padilla C., Lobos O., Hubert E., Gonzalez C., Matus S., Pereira M., Pereira M., Hasbun S., Descouvieres C. // J. Periodontal Res. 2006. V. 41. № 4. P. 350-353.

15. Rafferty B., Dolgilevich S., Kalachikov S., Morozova I., Ju J., Whittier S., Nowygrod R., Kozarov E. // J. Atheroscler. Thromb. 2011. V. 18. № 1. P. 72-81.

16. Lo J., Abbara S., Shturman L., Soni A., Wei J., Rocha-Filho J.A., Nasir K., Grinspoon S.K. // AIDS. 2010. V. 24. № 2. P. 243-253.

17. Pesonen E., El-Segaier M., Persson K., Puolakkainen M., Sarna S., Ohlin H., Pussinen P.J. // Ther. Adv. Cardiovasc. Dis. 2009. V. 3. № 6. P. 447-454.

18. Roizman B., Pellet P.E. Fields' Virology $5^{\text {th }}$ ed. N.Y.: Lippincott-Williams and Wilkins, 2007. P. 2479-2499.

19. Stowe R.P., Peek M.K., Cutchin M.P., Goodwin J.S. // J. Med. Virol. 2012. V. 84. № 11. P. 1797-1802.

20. Roberts E.T., Haan M.N., Dowd J.B., Aiello A.E. // Am. J. Epidemiol. 2010. V. 172. № 4. P. 363-371.

21. Simanek A.M., Dowd J.B., Pawelec G., Melzer D., Dutta A. // PLoS One. 2011. V. 6. № 2. e16103. 
22. Gredmark S., Jonasson L., van Gosliga D., Ernerudh J., Söderberg-Nauclér C. // Scandinavian Cardiovasc. J. 2007. V. 41. P. 230-234.

23. Tomtishen III J.P. // Virology J. 2012. V. 9. P. 22.

24. Ross S.A., Novak Z., Pati S., Boppana S.B. // Infect. Disord. Drug Targets. 2011. V. 11. P. 466-474.

25. Gimeno C., Solano C., Latorre J.C., Hernández-Boluda J.C., Clari M., Remigia M.J., Furió S., Calabuig M., Tormo N., Navarro D. // J. Clin. Microbiol. 2008. V. 46. P. 3311-3318.

26. Thygesen K., Alpert J.S., Jaffe A.S., Simoons M.L., Chaitman B.R., White H.D., Lindahl B., Morrow D.A., Chaitman B.A., Clemmensen P.M., et al. // Eur. Heart J. 2012. V. 33. P. 2551-2567.

27. Montalescot G., Sechtem U., Achenbach S., Andreotti F., Arden C., Budaj A., Bugiardini R., Crea F., Cuisset T., Di Mario C., et al. / / Eur. Heart J.2013. V.34. № 38. P. 2949-3003.

28. Lagrand L.K., Visser C.A., Hermens W.T., Niessen H.W., Verheugt F.W., Wolbink G.J., Hack C.E. // Circulation. 1999. V. 100. № 1. P. 96-102.

29. Tanabe K., Tokumoto T., Ishikawa N., Koyama I., Takahashi K., Fuchinoue S. // Transplantation. 1997. V. 64. № 12. P. 1721-1726.

30. Staras S.A., Dollard S.C., Radford K.W., Flanders W.D., Pass R.F., Cannon M.J. // Clin. Infect. Dis. 2006. V. 43. № 9. P. 1143-1151.

31. Ji Y.N., An L., Zhan P., Chen X.H. // Mol. Biol. Rep. 2012. V. 39. № 6. P. 6537-6546.

32. Nieto F.J., Adam E., Sorlie P., Farzadegan H., Melnick J.L., Comstock G.W., Szklo M. // Circulation. 1996. V. 94. № 5. P. 922-927.

33. Ridker P.M., Hennekens C.H., Stampfer M.J., Wang F. //
Circulation. 1998. V. 98. № 25. P. 2796-2799.

34. Smieja M., Chong S., Natarajan M., Petrich A., Rainen L., Mahony J.B. // J. Clin. Microbiol. 2001. V. 39. № 2. P. 596-600.

35. Melnick J.L., Petrie B.L., Dreesman G.R., Burek J., McCollum C.H., DeBakey M.E. // Lancet. 1983. V. 2. № 8351. P. 644-651.

36. Ridker P.M., Hennekens C.H., Buring J.E., Kundsin

R., Shih J. // Ann. Intern. Med. 1999. V. 131. № 8. P. 573-577.

37. Izadi M., Fazel M., Saadat S.H., Nasseri M.H., Ghasemi M., Dabiri H., Aryan R.S., Esfahani A.A., Ahmadi A., Kazemi-Saleh D., et al. // Cardiovasc. J. 2012. V. 8. № 2. P. 42-46.

38. Nikitskaya E.A., Grivel J.-C., Ivanova O.I., Lebedeva A.M., Shpektor A.V., Margolis L.B., Vasilieva E.Yu. // Creative Cardiology. 2014. № 4. P. 50-62.

39. Ferrante G., Nakano M., Prati F., Niccoli G., Mallus M.T., Ramazzotti V., Montone R.A., Kolodgie F.D., Virmani R., Crea F. // Circulation. 2010. V. 122. № 24. P. 2505-2513.

40. Nakajima T., Goek O., Zhang X., Kopecky S.L., Frye R.L., Goronzy J.J., Weyand C.M. // Circ. Res. 2003. V. 93. № 2. P. 106-113.

41. Liuzzo G., Stephen L., Kopecky S.L., Robert L., Frye, W., O’ Fallon M. // Circulation. 1999. V. 100. № 21. P. 2135-2139. 42. Weyand C.M., Goronzy J.J., Liuzzo G., Kopecky S.L., Holmes D.R., Frye R.L. // Mayo Clin. Proc. 2001. V. 76. № 10. P. 1011-1020.

43. Grivel J.-C., Ivanova O., Pinegina N., Blank P.S., Shpektor A., Margolis L.B., Vasilieva E. // Arterioscler. Thromb. Vasc. Biol. 2011. V. 31. № 12. P. 2929-2937.

44. Margolis L. // Am. J. Med. 2015. V. 128. № 6. P. 562-566. 


\title{
Inhibition of Poly(ADP-Ribose) Polymerase by Nucleic Acid Metabolite 7-Methylguanine
}

\author{
D. K. Nilov ${ }^{1,2}$, V. I. Tararov ${ }^{3}$, A. V. Kulikov ${ }^{4}$, A. L. Zakharenko ${ }^{5}$, I. V. Gushchina ${ }^{2}$, S. N. Mikhailov ${ }^{3}$, \\ O. I. Lavrik ${ }^{5}$, V. K. Švedas ${ }^{1,2^{*}}$ \\ ${ }^{1}$ Lomonosov Moscow State University, Belozersky Institute of Physicochemical Biology, Leninskie \\ Gory 1, bldg. 40, Moscow, 119991, Russia \\ ${ }^{2}$ Lomonosov Moscow State University, Faculty of Bioengineering and Bioinformatics, Leninskie \\ Gory 1, bldg. 73, Moscow, 119991, Russia \\ ${ }^{3}$ Engelhardt Institute of Molecular Biology, Russian Academy of Sciences, Vavilov str. 32, Moscow, \\ 119991, Russia \\ ${ }^{4}$ Lomonosov Moscow State University, Faculty of Fundamental Medicine, Lomonosovsky avenue \\ 31-5, Moscow, 119192, Russia \\ Institute of Chemical Biology and Fundamental Medicine, Russian Academy of Sciences, Siberian \\ Branch, Lavrentiev avenue 8, Novosibirsk, 630090, Russia \\ *E-mail: vyłas@belozersky.msu.ru \\ Received: 01.12 .2015 \\ Copyright (c) 2016 Park-media, Ltd. This is an open access article distributed under the Creative Commons Attribution License, which permits \\ unrestricted use, distribution, and reproduction in any medium, provided the original work is properly cited.
}

\begin{abstract}
The ability of 7-methylguanine, a nucleic acid metabolite, to inhibit poly(ADP-ribose)polymerase-1 (PARP-1) and poly(ADP-ribose)polymerase-2 (PARP-2) has been identified in silico and studied experimentally. The amino group at position 2 and the methyl group at position 7 were shown to be important substituents for the efficient binding of purine derivatives to PARPs. The activity of both tested enzymes, PARP-1 and PARP-2, was suppressed by 7 -methylguanine with $\mathrm{IC}_{50}$ values of 150 and $50 \mu \mathrm{M}$, respectively. At the PARP inhibitory concentration, 7-methylguanine itself was not cytotoxic, but it was able to accelerate apoptotic death of BRCA1-deficient breast cancer cells induced by cisplatin and doxorubicin, the widely used DNA-damaging chemotherapeutic agents. 7-Methylguanine possesses attractive predictable pharmacokinetics and an adverse-effect profile and may be considered as a new additive to chemotherapeutic treatment.
\end{abstract}

KEYWORDS PARP inhibitors, molecular modeling, docking. ABBREVIATIONS PARP - poly(ADP-ribose)polymerase, MD - molecular dynamics.

\section{INTRODUCTION}

Exposure of a human organism to different stress factors induces genotoxic DNA lesions that should be removed in order to ensure complete and accurate DNA replication and transcription, to avoid genomic instability, and to prevent, for example, cancer formation. Cellular repair pathways involve numerous proteins that recognize and clear DNA base modifications and DNA strand breaks [1]. Poly(ADP-ribose)polymerases (PARP; EC 2.4.2.30) are a group of eukaryotic proteins with diverse functions mainly related to DNA repair and cell death. The most studied PARP family members, PARP-1 and PARP-2, have DNA-damage-dependent enzymatic activity and catalyze the synthesis of poly(ADP-ribose) [2]. The donor of the ADP-ribose unit in the polymer synthesis is the $\mathrm{NAD}^{+}$molecule, and nicotinamide is released while a glycosidic bond between the units is formed. Binding of the PARP-1 and PARP-2 proteins to damaged DNA results in their poly(ADP-ribosyl)ation and that of the other proteins involved in DNA metabolism [3-6]. This kind of posttranslational modification leads to the activation and assembly of repair systems in the damaged locus of DNA: for example, automodified PARP-1 recruits the base excision repair protein XRCC1 associated with DNA polymerase $\beta$ and DNA ligase III [7-9]. The crucial role of PARP-1 and PARP-2 has been demonstrated by observations that both parp $-1^{-/-}$and parp$2^{-/-}$mice are more sensitive to ionizing radiation, and parp $-1^{-/-}$parp $-2^{-/-}$double mutants die early in development at the onset of gastrulation [10].

The DNA-binding domain (DBD) of PARP-1 is made of specialized zinc fingers, whereas the DBD structure of PARP-2 is unknown and has no sequence homology 
with any identified DNA-binding motif. In contrast, the catalytic domains and the active sites of PARP-1 and PARP-2 in the apo form, as well as in a complex with inhibitors, have extensive structural similarity [11,12]. The $\mathrm{NAD}^{+}$substrate bound in the active site interacts with Gly863 and Tyr907 residues (the numeration is for PARP-1) similar to inhibitors that mimic nicotinamide moiety. The Gly863 backbone forms two hydrogen bonds with the amide group of nicotinamide, while the Tyr907 side chain stacks with the nicotinamide ring [13]. Several known classes of PARP inhibitors are composed of a carbamoyl group attached to an aromatic ring or a lactam group built in an aromatic ring system [14-19], which makes possible the formation of the abovementioned interactions with the Gly863 and Tyr907 residues. Besides compounds competing with $\mathrm{NAD}^{+}$for the active site, the minor groove binding ligands may also serve as inhibitors that target the DNA-dependent pathway of PARP-1 regulation [20].

The PARP's involvement in DNA repair systems makes this enzyme an attractive target for anticancer therapy. Inhibitors of PARP-1 and PARP-2 may potentiate the effects of various DNA-damaging anticancer drugs, such as cisplatin or doxorubicin. When DNA is moderately damaged, PARPs participate in DNA repair so that cancer cells can survive. The combination of a DNA-damaging agent and PARP-1 or PARP-2 inhibitors can help to overcome drug resistance and promote apoptotic cell death, representing a promising strategy for cancer treatment [15, 21-23]. In addition, the use of inhibitors can exploit DNA repair defects in certain cancer cells. For example, the deficiency in homologous recombination in BRCA1/2-deficient cells makes them acutely sensitive to PARP inhibition [24-26]. Several PARP inhibitors tested as anticancer agents have failed to progress through preclinical or clinical trials because of their toxicity and insufficient efficacy [27-29]. In particular, a well-known PARP-1 inhibitor, 3-aminobenzamide, has a limited cell uptake and affects other metabolic processes. A first-in-class PARP-1 inhibitor, olaparib, was approved by the FDA in December 2014 as treatment for patients with advanced ovarian cancer [30]. This compound is a phthalazine derivative with a lactam group which decreases the enzyme's activity at a nanomolar concentration. Nevertheless, developing effective and non-toxic compounds targeting PARPs and able to suppress the progression of various types of cancers is an important, yet challenging task.

One of the promising classes of PARP inhibitors comprises natural nucleobases and their derivatives which contain a lactam group [31,32]. However, so far identified compounds (e.g., thymine, hypoxanthine) exert a relatively weak inhibitory effect. In this paper, we report on the results of a computer screening of nu- cleobase derivatives as PARP inhibitors and in vitro studies of the selected compounds.

\section{EXPERIMENTAL SECTION}

\section{Protein model preparation}

The initial model of PARP-1 was built on the basis of the 1efy crystallographic structure of the enzyme complex with inhibitor [33] using the AmberTools 1.2 program package (http://ambermd.org). Hydrogen atoms were added to the protein structure, and then it was solvated by a $12 \AA$-thick layer of TIP3P water. Chloride ions were added to neutralize the system. To perform the energy minimization of the obtained model, the protein molecule was described by the ff $99 S B$ force field [34] and the inhibitor molecule was described by GAFF parameters [35] calculated automatically. The energy minimization (2,500 steps of the steepest descent algorithm followed by 2,500 steps of the conjugate gradient algorithm) was performed using the Amber 10 package [36] in order to optimize the positions of hydrogen atoms. During the minimization, the heavy atoms of the protein and inhibitor were kept fixed by positional restraints $k(\Delta x)^{2}$, where the force constant $k$ was $2 \mathrm{kcal} /\left(\mathrm{mol} \AA^{2}\right)$. The inhibitor, water molecules, and chloride ions were removed from the system after the energy minimization to obtain a model for molecular docking.

\section{Molecular docking}

The computer library of natural nucleobase derivatives was prepared with the ACD/ChemSketch program [37]. Molecular docking was performed using the Lead Finder 1.1.14 program [38]. The energy grid map surrounding the active site of the PARP-1 model was calculated, and the library was screened using the genetic search algorithm. A series of 20 independent docking runs was performed for each compound, and the probability of a successful docking $P_{\text {dock }}$ was defined as the ratio of the number of successful runs meeting the specified structural criterion to the total number of runs; i.e., $P_{\text {dock }}=N_{\text {succ }} / 20$. The structural criterion was the presence of two hydrogen bonds between the lactam group of a docked compound and the Gly863 residue. Compounds with $P_{\text {dock }} \leq 0.8$ were sorted out automatically by a Perl script.

\section{Molecular dynamics simulation}

To include the selected potential inhibitor in the simulation, its parameters, except partial charges, were taken from the $f f 99 S B$ force field. To derive partial charges, the molecular electrostatic potential of the inhibitor was calculated at the $\mathrm{HF} / 6-31 \mathrm{G}^{*}$ level of theory with the PC GAMESS/Firefly program [39]. The 
fitting of partial atomic charges was done using the RESP method [40]. An equilibration and subsequent 10 ns molecular dynamics (MD) simulation of the PARP-1 in complex with the inhibitor were carried out using AmberTools 1.2 and Amber 10. A model of the complex obtained by molecular docking was solvated by a $12 \AA$-thick layer of TIP3P water and described by the $f f 99 S B$ force field. The energy minimization using the steepest descent and conjugate gradient algorithms was performed to relax the solvated system. The minimized system was heated up from 0 to $300 \mathrm{~K}$ over $50 \mathrm{ps}$ and then equilibrated over 500 ps at $300 \mathrm{~K}$. Finally, a $10 \mathrm{~ns}$ trajectory of an equilibrium simulation at constant pressure was calculated. All simulations were performed using periodic boundaries and the Particle Mesh Ewald method to calculate long-range electrostatic interactions.

The VMD 1.8.6 software [41] was used for the visualization of the structures. Parallel computations of the MD trajectory were performed at the Supercomputer Center, Lomonosov Moscow State University [42].

\section{Synthesis of compounds}

7-Methylguanine, 7-methylxanthine, 7-methylhypoxanthine, and 7-ethylguanine were prepared by alkylation of the corresponding nucleosides, followed by $\mathrm{N}$-glycosidic bond cleavage according to the earlier described procedures $[43,44]$.

7-Methylguanine. $400 \mathrm{MHz}{ }^{1} \mathrm{H}$ NMR (DMSO- $\mathrm{d}_{6}$ ): $\delta=3.82(\mathrm{~s}, 3 \mathrm{H}, \mathrm{Me}), 6.03$ (brs, $\left.2 \mathrm{H}, \mathrm{NH}_{2}\right), 7.81(\mathrm{~s}, 1 \mathrm{H}, \mathrm{H}-8)$, 10.66 (brs, $1 \mathrm{H}, \mathrm{NH})$.

7-Methylxanthine. $400 \mathrm{MHz}{ }^{1} \mathrm{H}$ NMR (DMSO- $\mathrm{d}_{6}$ ): $\delta=3.81(\mathrm{~s}, 3 \mathrm{H}, \mathrm{Me}), 7.85$ (s, $1 \mathrm{H}, \mathrm{H}-8), 10.79$ (brs, $1 \mathrm{H}$, $\mathrm{NH}), 11.48$ (brs, $1 \mathrm{H}, \mathrm{NH})$.

7 -Methylhypoxanthine. $400 \mathrm{MHz}{ }^{1} \mathrm{H}$ NMR (CD$\left.\mathrm{Cl}_{3}-\mathrm{CD}_{3} \mathrm{OD}\right): \delta=3.94(\mathrm{~s}, 3 \mathrm{H}, \mathrm{Me}), 7.80(\mathrm{~s}, 1 \mathrm{H}, \mathrm{H}-2), 7.84$ (s, $1 \mathrm{H}, \mathrm{H}-8)$.

7-Ethylguanine. $400 \mathrm{MHz}{ }^{1} \mathrm{H}$ NMR (DMSO- $\mathrm{d}_{6}$ ): $\delta=1.36\left(\mathrm{t}, 3 \mathrm{H}, \mathrm{J}=7.2 \mathrm{~Hz}, \mathrm{CH}_{3}\right), 4.19(\mathrm{q}, 2 \mathrm{H}, \mathrm{Me}, \mathrm{J}=$ $7.2 \mathrm{~Hz}, \mathrm{CH}_{2}$ ), 6.09 (brs, 2H, $\mathrm{NH}_{2}$ ), 7.90 (s, $\left.1 \mathrm{H}, \mathrm{H}-8\right), 10.26$ (brs, $1 \mathrm{H}, \mathrm{NH}$ ).

\section{Enzyme assay}

Recombinant human PARP-1 and murine PARP2 proteins were purified as described previously [ 45 , 46]. Reaction of poly(ADP-ribosyl)ation catalyzed by PARP-1 and PARP-2 was performed at optimal conditions for each enzyme [47,48]. Briefly, for PARP-1: $50 \mathrm{mM}$ Tris- $\mathrm{HCl} \mathrm{pH} \mathrm{8.0,20} \mathrm{mM} \mathrm{MgCl}_{2}, 150 \mathrm{mM} \mathrm{NaCl}$, $7 \mathrm{mM} \beta$-mercaptoethanol, activated DNA $\left(2\right.$ o.u. $_{280} / \mathrm{ml}$, degree of activation $25 \%), 300 \mu \mathrm{M} \mathrm{NAD}{ }^{+}(0.18 \mu \mathrm{Ci}$ $\left.\left[{ }^{3} \mathrm{H}\right] \mathrm{NAD}^{+}\right), 37^{\circ} \mathrm{C}$. The reaction was started by adding PARP-1 up to a final concentration of $0.2 \mu \mathrm{M}$ and was stopped after $1 \mathrm{~min}$, placing the reaction mixture on paper filters (Whatman-1) soaked with a 5\% solution of trichloroacetic acid. For PARP-2: $50 \mathrm{mM}$ Tris-HCl pH $8.0,40 \mathrm{mM} \mathrm{NaCl}, 0.1 \mathrm{mg} / \mathrm{ml} \mathrm{BSA}, 8 \mathrm{mM} \mathrm{MgCl}_{2}, 1 \mathrm{mM}$ DTT, activated DNA ( 2 o.u. $_{280} / \mathrm{ml}$, degree of activation $25 \%), 400 \mu \mathrm{MINAD}{ }^{+}\left(0.4 \mu \mathrm{Ci}\left[{ }^{3} \mathrm{H}\right] \mathrm{NAD}^{+}\right), 37^{\circ} \mathrm{C}$. The reaction was started by adding PARP-2 up to a final concentration of $0.2 \mu \mathrm{M}$ and was stopped after $5 \mathrm{~min}$, placing the reaction mixture on the paper filters. The filters were washed four times by the $5 \%$ trichloroacetic acid, then by $90 \%$ ethanol (to remove acid), and air-dried. The quantity of radiolabel included into the acid insoluble product was registered on a scintillation counter Tri-Carb 2800 (Perkin Elmer) in a toluene scintillator. The quantity of the radiolabeled product was determined at the initial rate period.

The PARP-inhibiting activity of the synthesized compounds was evaluated in a reaction of auto-poly(ADP-ribosyl)ation at a $\mathrm{NAD}^{+}$concentration of $0.3 \mathrm{mM}$ for PARP-1 and $0.4 \mathrm{mM}$ for PARP-2. Different concentrations of the tested compounds were added to the reaction mixture before adding the enzyme. Reaction and detection of the products were performed as described above. To determine the $\mathrm{IC}_{50}$ value (concentration of the compound required to reduce the enzyme activity by $50 \%$ ), the effect of different concentrations of the inhibitor on the enzyme activity was examined. Measurements were done in at least two independent experiments. $\mathrm{IC}_{50}$ values were calculated using the Origin Pro 8.0 software by nonlinear regression analysis.

\section{Cytotoxicity assay}

The cytotoxic activity of 7-methylguanine, cisplatin, doxorubicin, and their combinations was evaluated by the analysis of cell cycle distribution and measurement of the Sub-G1 population by flow cytometry, as well as by measurement of caspase-3-like activity as a marker of the apoptotic pathway. A BRCA1-deficient human breast cancer line HCC1937 (ATCC CRL-2336) was cultured in DMEM supplemented with $10 \%$ heat-inactivated fetal bovine serum, penicillin/streptomycin $(100 \mathrm{U} / \mathrm{ml})$, and pyruvate $(0,11 \mathrm{mg} / \mathrm{ml})$ at $37^{\circ} \mathrm{C}$ in $20 \%$ $\mathrm{O}_{2}$ humidified atmosphere. The cells were maintained in a logarithmic growth phase for all experiments. After $24 \mathrm{~h}$ of culturing, the cells were pretreated with 7 -methylguanine $(150 \mu \mathrm{M})$ for $3 \mathrm{~h}$, followed by addition of either cisplatin $(70 \mu \mathrm{M})$ or doxorubicin $(1 \mu \mathrm{M})$.

To perform cell cycle analysis, the cells were then harvested after 72 hours, fixed with $70 \% \mathrm{EtOH}$ (final concentration) for $60 \mathrm{~min}$ on ice, rinsed in PBS, and stained in a $500 \mu \mathrm{l}$ solution containing $50 \mu \mathrm{g} / \mathrm{ml}$ propidium iodide and $25 \mu \mathrm{g} / \mathrm{ml}$ RNase A for $15 \mathrm{~min}$. Data were acquired by a BD FACS CantoII flow cytometer (BD Biosciences) and analyzed using the FACSDiva software. The cleavage of the fluorogenic 
peptide substrate Ac-DNLDAMC was measured using a fluorometric assay. Upon treatment with cytotoxic agents, the cells were incubated for 48 hours, then harvested and washed with PBS. After centrifugation, they were re-suspended in PBS at a concentration of $2 \times 10^{6}$ cells $/ 100 \mu$ l. Then, $25 \mu \mathrm{l}$ of the suspension was added to a 96 -well plate and mixed with a DEVD peptide substrate dissolved in a standard reaction buffer (100 mM HEPES, $10 \%$ sucrose, $5 \mathrm{mM}$ DTT, $0.001 \% \mathrm{NP}-$ 40 , and $0.1 \%$ CHAPS, $\mathrm{pH} 7.2$ ). Cleavage of the fluorogenic peptide substrate was monitored by AMC liberation in a VarioScan Flash multimode detector (Thermo Scientific) using $380 \mathrm{~nm}$ excitation and $460 \mathrm{~nm}$ emission wavelengths. Measurements were done in at least two independent experiments.

\section{Pharmacokinetics and adverse-effect modeling} Pharmacokinetics and adverse-effect profiling of 7-methylguanine was done with ACD/Percepta [49]. This software in silico predicts ADME properties (absorption, distribution, metabolism, excretion) and toxicity by QSAR models based on an analysis of similar compounds from the experimental data library. In case of 7-methylguanine, among library compounds were acyclovir, caffeine, theobromine, and theophylline.

\section{RESULTS AND DISCUSSION}

\section{Virtual screening}

A model of PARP-1, the most characterized member of the PARP family, was built on the basis of the crystallographic structure of the catalytic fragment in a complex with the inhibitor (PDB ID 1efy, $2.2 \AA$ resolution). Hydrogen atoms were added taking into account ionization of amino acid side chains, and then their positions were optimized to achieve complementarity to the inhibitor scaffold. A computer library of natural nucleobase derivatives with a lactam structural fragment was prepared comprising nearly a hundred diverse purine and pyrimidine modifications which could be synthesized on a preparative scale. Virtual screening for derivatives able to bind in the active site of the PARP-1 was performed by molecular docking. In order to provide a better sampling of the conformational space, a series of 20 independent docking runs was performed for each compound in the library. Then, we applied the procedure of structural filtration, which allows one to sort out false-positive docking results [47]. As it has been noticed previously, the substrate and the known PARP inhibitors have a common structural feature - their amide (or lactam) group forms two hydrogen bonds with the Gly863 residue. This interaction is apparently crucial for an effective binding in the PARP active site and was used as a criterion for selection of potential inhibitors. Docking poses of compounds meeting the structural criterion were further analyzed for favorable hydrophobic contacts as well as electrostatic interactions in the PARP-1 active site, and the 7-methylguanine molecule $\left(P_{\text {dock }}=0.95, \Delta G\right.$ calc $=-6.8 \mathrm{kcal} / \mathrm{mol}$ ) was selected as the most promising PARP inhibitor.

MD simulations were further performed to evaluate the geometric characteristics of 7-methylguanine in the PARP-1 active site and examine the stability of the enzyme-inhibitor complex. The formation of two hydrogen bonds between the lactam group of 7-methylguanine and the Gly863 residue was observed along the MD trajectories as well as the pi stacking of purine rings with the side chain of Tyr907 and the hydrophobic interaction of the methyl group at position 7 with the Ala898 side chain (Fig. 1). We also revealed an electrostatic interaction between the amino group of 7-methylguanine at position 2 and the backbone oxygen of Gly263, which appeared to be a non-conventional hydrogen bond. The mean $\mathrm{NH}_{2}: \mathrm{H} \cdots \mathrm{Gly} 863: \mathrm{O}$ distance was $2.42 \AA$, and the mean $\mathrm{NH}_{2}: \mathrm{N}^{2} \cdots \mathrm{NH}_{2}: \mathrm{H} \cdots \mathrm{Gly} 863: \mathrm{O}$ angle $137^{\circ}$, whereas the corresponding distance of a regular hydrogen bond is expected to be $1.8-2.1 \AA$ and the angle not less than $150^{\circ}$. Distance and angle characteristics are presented in Table 1.

Interestingly, the structural analogue of 7-methylguanine, namely, 7-methylxanthine, was previously shown to be a moderate inhibitor of PARP-1 [32]. This compound differs from 7-methylguanine by an oxo substituent at position 2 (Fig. 2). However, 7-methylxanthine was sorted out by our procedure of structural filtration $\left(P_{\text {dock }}=0.45\right)$, indicating that its binding has to be less effective. We also docked 7-methylhypoxanthine, analogue with no substituent at position 2 , and the predicted binding parameters $\left(P_{\text {dock }}=0.85\right.$, $\Delta G^{\text {calc }}=-6.4 \mathrm{kcal} / \mathrm{mol}$ ) were less encouraging, as well. Analysis of the modeled poses demonstrated that the amino group at position 2 can substantially increase the effectiveness of the inhibitor's binding in the PARP active site due to the favorable electrostatic interaction with Gly863. The methyl group at position 7 is another substituent responsible for the complementarity of the inhibitor to the PARP-1 active site, as the unmodified xanthine does not show inhibition [32]. However, the calculated parameters of 7-ethylguanine binding $\left(P_{\text {dock }}=0.7, \Delta G^{\text {calc }}=-6.7 \mathrm{kcal} / \mathrm{mol}\right)$ indicate that the inhibitory effect cannot be further increased with a growing alkyl chain at this position.

\section{Inhibitory properties of purine derivatives}

We synthesized 7-methylguanine, 7-methylxanthine, 7-methylhypoxanthine, and 7-ethylguanine to test their ability to suppress PARP and assess the effect 


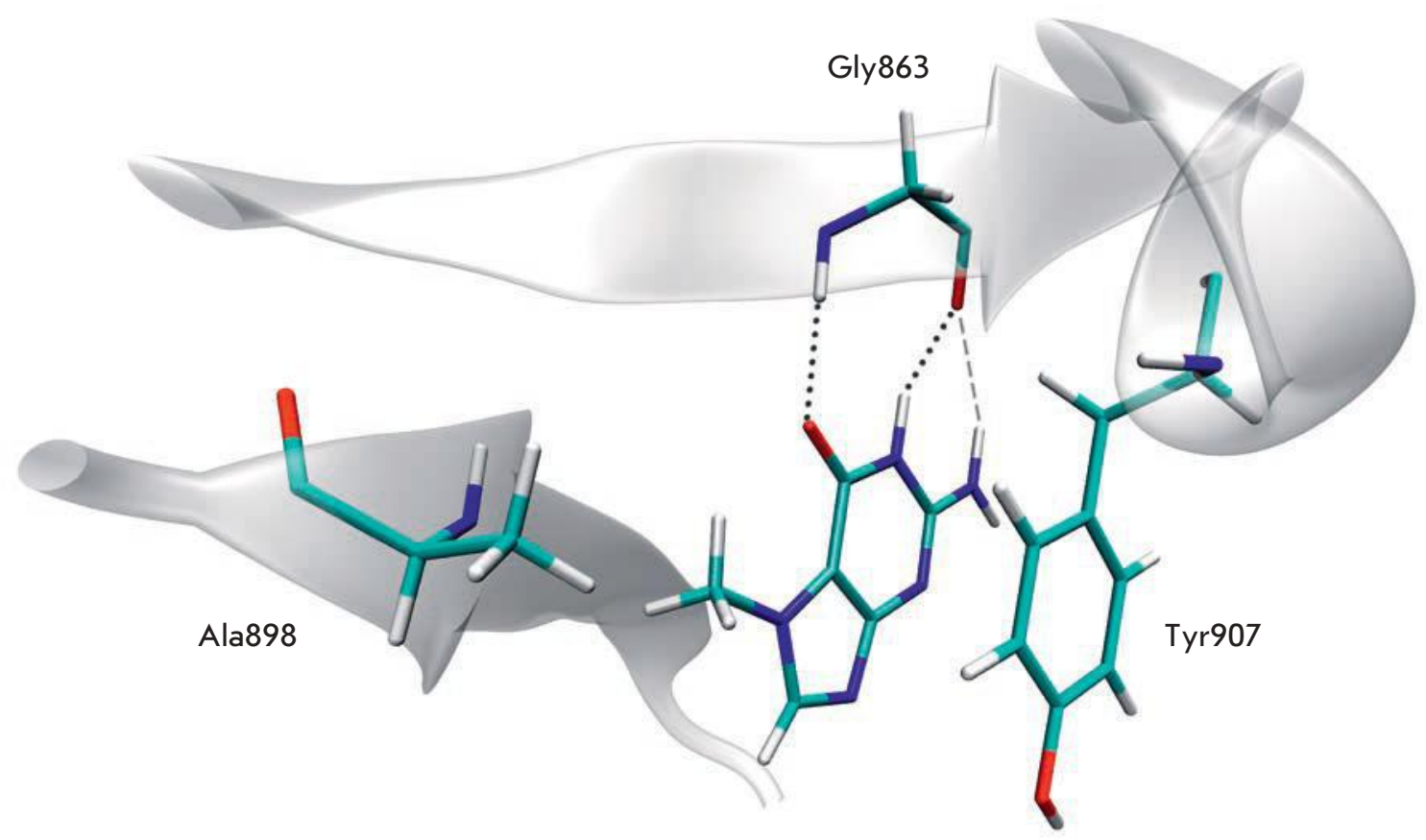

Fig. 1. The position and interactions of the 7-methylguanine molecule in the PARP-1 active site revealed by molecular modeling: two hydrogen bonds of the lactam group with Gly863 shown as dotted lines, an electrostatic interaction of the amino group as dashed line, pi stacking of purine rings with Tyr907, and hydrophobic interaction of the methyl group with Ala898.<smiles>Cn1cnc2nc(N)[nH]c(=O)c21</smiles>

7-methylguanine<smiles>Cn1cnc2nc[nH]c(=O)c21</smiles>

7-methylhypoxanthine<smiles>Cn1cnc2[nH]c(=O)[nH]c(=O)c21</smiles>

7-methylxanthine<smiles>CCn1cnc2nc(N)[nH]c(=O)c21</smiles>

7-ethylguanine

Fig. 2. Chemical structures of the synthesized and tested compounds.

of the substituent on the activity of the inhibitor. The inhibitory properties of 7-methylguanine and related compounds were studied using two purified proteins of the PARP family - human PARP-1 and murine PARP-2. Experimental data presented in Table 2 demonstrate that 7-methylguanine, as predicted, is

Table 1. Distance and angle characteristics of the position of 7-methylguanine (7-MG) in the PARP-1 active site determined by MD simulations. Mean values are presented together with the standard deviations.

\begin{tabular}{|c|c|}
\hline \multicolumn{2}{|l|}{ Distance $(\AA)$} \\
\hline 7-MG:CO:O $\cdots$ Gly863:H & $2.0 \pm 0.2$ \\
\hline 7-MG:NH:H $\cdots$ Gly863:O & $1.9 \pm 0.1$ \\
\hline 7-MG: $\mathrm{NH}_{2}: \mathrm{H} \cdots \mathrm{Gly} 863: \mathrm{O}$ & $2.4 \pm 0.4$ \\
\hline 7-MG: $\mathrm{CH}_{3}: \mathrm{C} \cdots$ Ala 898:CB & $4.0 \pm 0.3$ \\
\hline$C\left(7-\mathrm{MG}\right.$ fused rings) ${ }^{\cdots} C$ (Tyr907 benzene ring) ${ }^{*}$ & $3.6 \pm 0.2$ \\
\hline \multicolumn{2}{|l|}{ Angle (deg) } \\
\hline 7-MG:CO:O $\cdots$ Gly863:H $\cdots$ Gly863:N & $160 \pm 11$ \\
\hline 7-MG:NH:N $\cdots 7-M G: N H: H ~ \cdots ~ G l y 863: O$ & $159 \pm 9$ \\
\hline 7-MG:NH $: \mathrm{NH}_{2} \cdots 7-\mathrm{MG}: \mathrm{NH}: \mathrm{H} \cdots \mathrm{Gly} 863: \mathrm{O}$ & $137 \pm 10$ \\
\hline
\end{tabular}

"Distance between the geometric center of 7-methylguanine fused rings and the center of the Tyr907 benzene ring.

the most effective inhibitor, with $\mathrm{IC}_{50}$ values of 150 and $50 \mu \mathrm{M}$ for PARP-1 and PARP-2, respectively. Replacement of the 2-oxo group of 7-methylxanthine by the amino group led to a 5- and 3-fold increase in the ability to inhibit PARP-1 and PARP-2. 7-Methylguanine was a more effective inhibitor compared to 7-ethyl- 
Control

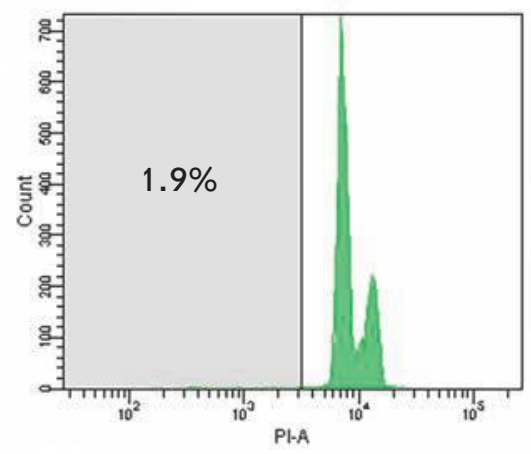

7-MG $(150 \mu M)$

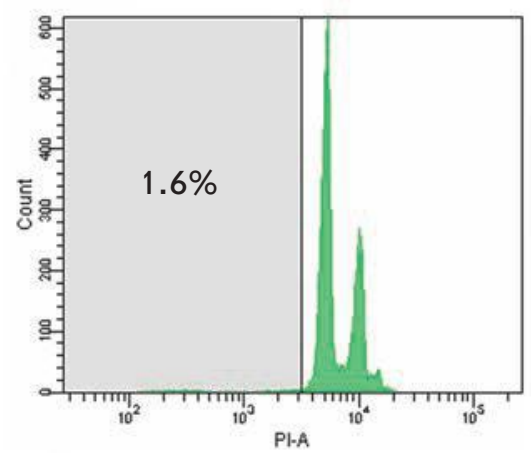

Cis $(70 \mu M)$

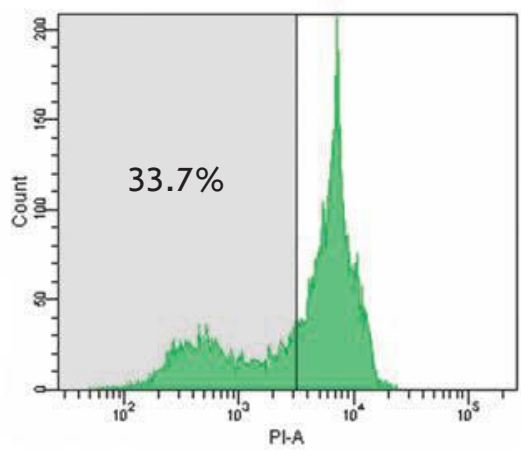

Cis $(70 \mu M)+7-M G(150 \mu M)$

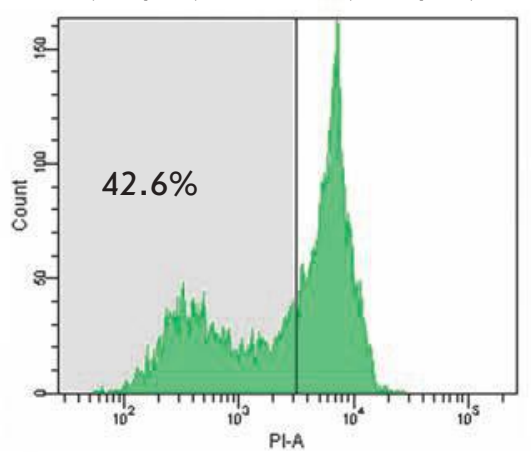

$\operatorname{Dox}(1 \mu M)$

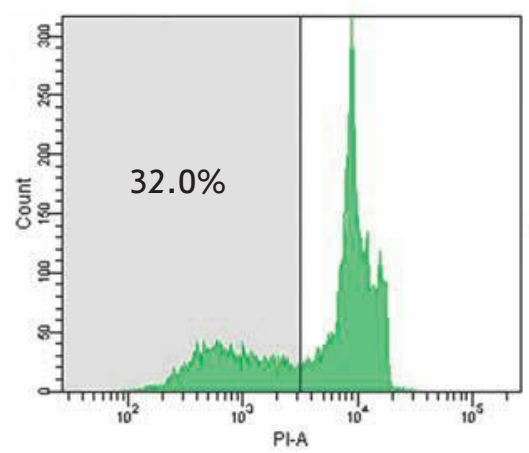

$\operatorname{Dox}(1 \mu M)+7-M G(150 \mu M)$

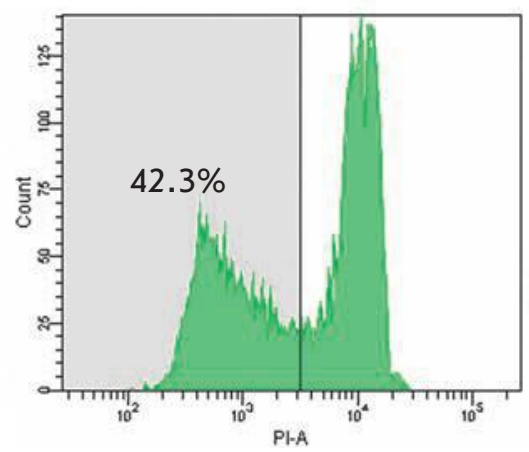

Fig. 3. Estimation of the Sub-G1 population of HCC1937 cells subjected to cisplatin (Cis), doxorubicin (Dox), and 7-methylguanine (7-MG) in single and combined treatment for $72 \mathrm{~h}$. The area of the Sub-G1 population is shown in gray.

guanine, indicating that the methyl group is an optimal alkyl substituent at this position. It is worth mentioning that all tested purine derivatives were more effective inhibitors of PARP-2 despite the very similar organization of the binding sites of both enzymes. We can assume that the reason for this selectivity is the different inhibitor delivery trajectories to the active centers of the PARP proteins.

\section{Analysis of cytotoxicity}

Analysis of cytotoxicity was performed on a human breast cancer line HCC1937, which is thought to be sensitive to the inhibition of PARP due to deficiency in the DNA repair gene BRCA1 [22, 50, 51]. Cell death induced by the conventional anticancer drugs cisplatin and doxorubicin and by 7-methylguanine was estimated by flow cytometry analysis of a Sub-G1 population, which corresponds to an apoptotic cell population with fragmented DNA (Fig. 3). Treatment of the cells with 7-methylguanine itself did not increase the cells' number in the Sub-G1 phase (it was around 2\%), which was comparable to the control. Comparison of cell death level revealed that 7-methylguanine sensitizes HCC1937 to treatment with cisplatin and doxorubicin. With the
Table 2. Inhibitory effect of 7-methylguanine and related compounds on PARP-1 and PARP-2.

\begin{tabular}{|c|c|c|}
\hline \multirow{2}{*}{} & \multicolumn{2}{|c|}{$\mathrm{IC}_{50}(\mu \mathrm{M})$} \\
\cline { 2 - 3 } & PARP-1 & PARP-2 \\
\hline 7-methylguanine & 150 & 50 \\
\hline 7-methylxanthine & 800 & 160 \\
\hline 7-methylhypoxanthine & 780 & 620 \\
\hline 7-ethylguanine & 230 & 90 \\
\hline
\end{tabular}

exposure of cells to a combination of 7-methylguanine and $70 \mu \mathrm{M}$ cisplatin, the population of cells in the Sub-G1 phase increased from $34 \%$ to $43 \%$ and addition of 7-methylguanine to $1 \mu \mathrm{M}$ doxorubicin increased the Sub-G1 population from $32 \%$ to $42 \%$. Thus, the level of cell death elevation at addition of 7-methylguanine was very similar in the cases of cisplatin and doxorubicin.

We also analyzed the activation of caspase- 3 in HCC1937 cells, which is an important and obligatory event in the apoptotic cell death program. Active caspase- 3 cleaves various cellular molecules, which re- 
sults in apoptotic morphology of cells. Thus, the degree of caspase- 3 activation, measured by cleavage of the specific fluorogenic substrate, corresponds to the level of apoptotic cell death. Figure 4 demonstrates that stimulation of caspase- 3 activity was increased by the addition of 7-methylguanine to either cisplatin or doxorubicin by $27-39 \%$, whereas 7 -methylguanine alone demonstrated no caspase- 3 activation. These data are in agreement with cell death induction observed by flow cytometry.

Pharmacokinetics and adverse-effect profiling Finally, we evaluated the pharmacokinetic properties and adverse-effect profile of 7-methylguanine using QSAR models based on literature data on its structural analogues (acyclovir, caffeine, theobromine, theophylline, etc.). In particular, human intestinal permeability was estimated to be very high, and the oral bioavailability was predicted to be optimal (83\%). The calculated plasma protein bound fraction of 7-methylguanine was $17 \%$, which should not considerably affect its efficiency. It is unlikely that 7-methylguanine binds to estrogen receptor alpha (no risk of reproductive toxicity), hERG potassium ion channel (no risk of cardiotoxicity), P-glycoprotein efflux transporter, and cytochrome P450 enzymes (CYP3A4, CYP2D6, CYP2C9, CYP2C19, CYP1A2). Thus, the predicted properties provide evidence of the safety and efficacy of 7-methylguanine for humans.

\section{CONCLUSIONS}

Despite the ability of DNA-damaging drugs to kill cancer cells, resistance to chemotherapy and drug toxicity remain serious problems. DNA repair systems involving PARP-1 and PARP-2 play an important role in the normal development of the organism, but in anticancer treatment with DNA-damaging agents these proteins may decrease the therapeutic effect. A nucleic acid metabolite 7-methylguanine was identified in silico as a novel inhibitor of PARP catalytic activity and studied experimentally. Two structural features of purine derivatives were shown to be important for efficient binding - the amino group at position 2 and the me-

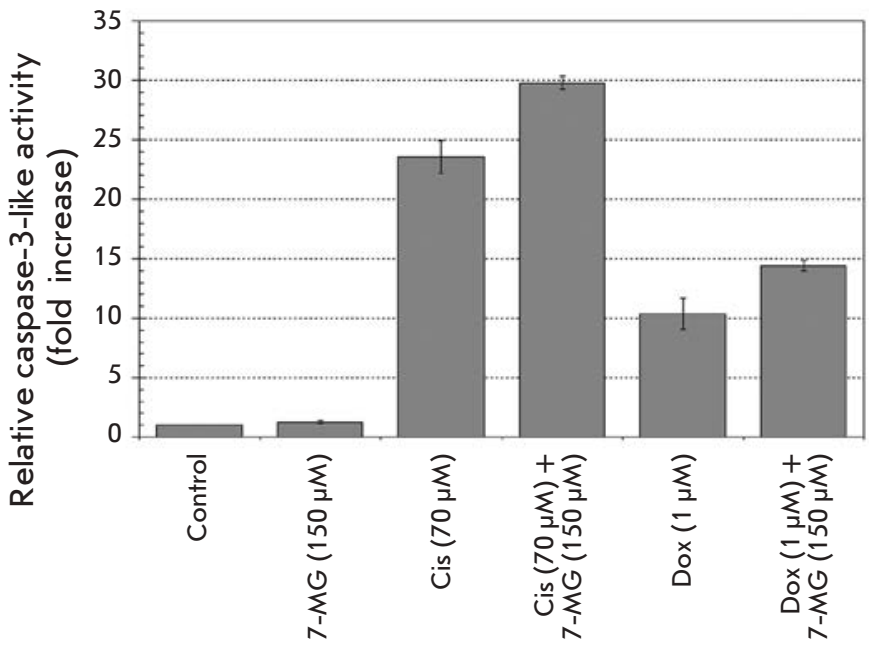

Fig. 4. Estimation of caspase-3-like activity in HCC1937 cells subjected to cisplatin (Cis), doxorubicin (Dox), and 7-methylguanine (7-MG) in single and combined treatment for $48 \mathrm{~h}$.

thyl group at position 7. At PARP inhibitory concentration, 7-methylguanine itself was not cytotoxic but able to sensitize BRCA1-deficient breast cancer cells to commonly used chemotherapeutic agents (cisplatin and doxorubicin). 7-Methylguanine is a nucleic acid metabolite observed in human serum and excreted in urine [52]. Despite the fact that 7-methylguanine is a weaker inhibitor than olaparib and some other PARP inhibitors, we believe that this natural compound possesses better pharmacokinetics and an adverse-effect profile compared to synthetic inhibitors and may be considered as a promising new constituent of anticancer therapy.

This work was supported by the Russian Ministry of Education and Science (State agreement № 14.604.21.0018, ID RFMEFI60414X0018). The chemical synthesis of purines was supported by the Russian Foundation for Basic Research (grant 14-04-00835_a).
REFERENCES

1. Cline S.D., Hanawalt P.C. // Nat. Rev. Mol. Cell Biol. 2003. V. 4. P. 361-373.

2. Drenichev M.S., Mikhailov S.N. // Nucleosides Nucleotides Nucleic Acids. 2015. V. 34. P. 258-276.

3. Lautier D., Lagueux J., Thibodeau J., Ménard L., Poirier

G.G. // Mol. Cell. Biochem. 1993. V. 122. P. 171-193.

4. Schreiber V., Dantzer F., Ame J.-C., de Murcia G. // Nat.

Rev. Mol. Cell Biol. 2006. V. 7. P. 517-528.
5. Hassa P.O., Haenni S.S., Elser M., Hottiger M.O. // Microbiol. Mol. Biol. Rev. 2006. V. 70. P. 789-829.

6. Hassler M., Ladurner A.G. // Curr. Opin. Struct. Biol. 2012. V. 22. P. 721-729.

7. Masson M., Niedergang C., Schreiber V., Muller S., Menissier-de Murcia J., de Murcia G. // Mol. Cell. Biol. 1998. V. 18. P. 3563-3571.

8. Ryu K.W., Kim D.-S., Kraus W.L. // Chem. Rev. 2015. V. 115. P. 2453-2481. 
9. Cazzalini O., Donà F., Savio M., Tillhon M., Maccario C., Perucca P., Stivala L.A., Scovassi A.I., Prosperi. E. // DNA Repair (Amst.). 2010. V. 9. P. 627-635.

10. Ménissier de Murcia J., Ricoul M., Tartier L., Niedergang C., Huber A., Dantzer F., Schreiber V., Amé J.C., Dierich A., LeMeur M. et al. // EMBO J. 2003. V. 22. P. 2255-2263.

11. Ruf A., Mennissier de Murcia J., de Murcia G., Schulz G.E. // Proc. Natl. Acad. Sci. USA. 1996. V. 93. P. 7481-7485.

12. Karlberg T., Hammarström M., Schütz P., Svensson L., Schüler H. // Biochemistry. 2010. V. 49. P. 1056-1058.

13. Ruf A., de Murcia G., Schulz G.E. // Biochemistry. 1998. V. 37. P. 3893-3900.

14. Banasik M., Komura H., Shimoyama M., Ueda K. // J. Biol. Chem. 1992. V. 267. P. 1569-1575.

15. Jagtap P., Szabó C. // Nat. Rev. Drug Discov. 2005. V. 4. P. 421-440.

16. Ferraris D.V. // J. Med. Chem. 2010. V. 53. P. 4561-4584.

17. Ekblad T., Camaioni E., Schüler H., Macchiarulo A. // FEBS J. 2013. V. 280. P. 3563-3575.

18. Efremova A.S., Zakharenko A.L., Shram S.I., Kulikova I.V., Drenichev M.S., Sukhanova M.V., Khodyreva S.N., Myasoedov N.F., Lavrik O.I., Mikhailov S.N. // Nucleosides Nucleotides Nucleic Acids. 2013. V. 32. P. 510-528.

19. Ekblad T., Lindgren A.E.G., Andersson C.D., Caraballo R., Thorsell A.-G., Karlberg T., Spjut S., Linusson A., Schüler

H., Elofsson M. // Eur. J. Med. Chem. 2015. V. 95. P. 546-551.

20. Kirsanov K.I., Kotova E., Makhov P., Golovine K., Lesovaya E.A., Kolenko V.M., Yakubovskaya M.G., Tulin A.V. // Oncotarget. 2014. V. 5. P. 428-437.

21. Cepeda V., Fuertes M.A., Castilla J., Alonso C., Quevedo C., Soto M., Pérez J.M. // Recent Pat. Anticancer Drug Discov. 2006. V. 1. P. 39-53.

22. Martin S.A., Lord C.J., Ashworth A. // Curr. Opin. Genet. Dev. 2008. V. 18. P. 80-86.

23. Brock W.A., Milas L., Bergh S., Lo R., Szabó C., Mason

K.A. // Cancer Lett. 2004. V. 205. P. 155-160.

24. Curtin N.J., Szabo C. // Mol. Aspects Med. 2013. V. 34. P. 1217-1256.

25. Farmer H., McCabe N., Lord C.J., Tutt A.N.J., Johnson D.A., Richardson T.B., Santarosa M., Dillon K.J., Hickson I., Knights C., et al. // Nature. 2005. V. 434. P. 917-921.

26. Boerner J.L., Nechiporchik N., Mueller K.L., Polin L., Heilbrun L., Boerner S.A., Zoratti G.L., Stark, K., LoRusso, P.M., Burger, A. // PLoS One. 2015. V. 10. P. e0119614.

27. Milam K.M., Cleaver J.E. // Science. 1984. V. 223. P. $589-$ 591.

28. Mateo J., Ong M., Tan D.S.P., Gonzalez M.A., de Bono J.S. // Nat. Rev. Clin. Oncol. 2013. V. 10. P. 688-696.

29. Madison D.L., Stauffer D., Lundblad J.R. // DNA Repair (Amst.). 2011. V. 10. P. 1003-1013.

30. Frampton J.E. // BioDrugs. 2015. V. 29. P. 143-150.
31. Virág L., Szabó C. // FASEB J. 2001. V. 15. P. 99-107. 32. Geraets L., Moonen H.J.J., Wouters E.F.M., Bast A., Hageman G.J. // Biochem. Pharmacol. 2006. V. 72. P. 902-910.

33. White A.W., Almassy R., Calvert A.H., Curtin N.J., Griffin R.J., Hostomsky Z., Maegley K., Newell D.R., Srinivasan S., Golding B.T. // J. Med. Chem. 2000. V. 43. P. 4084-4097.

34. Hornak V., Abel R., Okur A., Strockbine B., Roitberg A., Simmerling C. // Proteins. 2006. V. 65. P. 712-725.

35. Wang J., Wolf R.M., Caldwell J.W., Kollman P.A., Case D.A. // J. Comput. Chem. 2004. V. 25. P. 1157-1174.

36. Case D.A., Darden T.A., Cheatham T.E., III, Simmerling C.L., Wang J., Duke R.E., Luo R., Crowley M., Walker R.C., Zhang W., et al. // AMBER 10. University of California, San Francisco. 2008.

37. ACD/ChemSketch Freeware, version 8.17. Advanced Chemistry Development, Inc., http://www.acdlabs.com. 2005.

38. Stroganov O.V., Novikov F.N., Stroylov V.S., Kulkov V., Chilov G.G. // J. Chem. Inf. Model. 2008. V. 48. P. 2371-2385.

39. Granovsky A.A. Firefly, version 7.1.F, http://classic.chem. msu.su/gran/firefly/index.html. 2009.

40. Bayly C.I., Cieplak P., Cornell W.D., Kollman P.A. // J. Phys. Chem.; 1993. V. 97. P. 10269-10280.

41. Humphrey W., Dalke A., Schulten K. // J. Mol. Graph. 1996. V. 14. P. 33-38.

42. Voevodin Vl.V., Zhumatiy S.A., Sobolev S.I., Antonov A.S., Bryzgalov P.A., Nikitenko D.A., Stefanov K.S., Voevodin Vad.V. // Open Systems J. (Mosc.). 2012. V. 7. P. 36-39.

43. Jones J.W., Robins R.K. // J. Am. Chem. Soc. 1963. V. 85. P. $193-201$.

44. Vidal A., Giraud I., Madelmont J.-C. // Synth. Commun. 2004. V. 34. P. 3359-3365.

45. Sukhanova M.V., Khodyreva S.N., Lavrik O.I. // Biochemistry (Mosc.). 2004. V. 69, P. 558-568.

46. Amé J.C., Rolli V., Schreiber V., Niedergang C., Apiou F., Decker P., Muller S., Höger T., Ménissier-de Murcia J., de Murcia G. // J. Biol. Chem. 1999. V. 274. P. 17860-17868.

47. Zakharenko A.L., Sukhanova M.V., Khodyreva S.N., Novikov F.N., Stroylov V.S., Nilov D.K., Chilov G.G., Švedas V.K., Lavrik O.I. // Mol. Biol. (Mosc.). 2011. V.45. P. 517-521.

48. Kutuzov M.M., Khodyreva S.N., Amé J.-C., Ilina E.S., Sukhanova M.V., Schreiber V., Lavrik O.I. // Biochimie. 2013. V. 95. P. 1208-1215.

49. ACD/Percepta. Advanced Chemistry Development, Inc., http://www.acdlabs.com. 2012.

50. Benafif S., Hall M. // Onco Targets Ther. 2015. V. 8. P. 519-528.

51. Helleday T. // Mol. Oncol. 2011. V. 5. P. 387-393.

52. Topp H., Sander G., Heller-Schöch G., Schöch G.. // Anal. Biochem. 1987. V. 161. P. 49-56. 